\title{
Pembelajaran Sains Untuk Mengenalkan Kebencanaan Pada Anak Usia Dini
}

\author{
Aldila Rahma \\ Pendidikan Guru Pendidikan Anak Usia Dini Universitas Islam Nusantara \\ Email: aldila.rahma@fkip-uninus.ac.id
}

\begin{abstract}
Abstrak.
Anak-anak adalah bagian anggota masyarakat yang rentan terhadap bencana karena keterbatasan pengalaman, pengetahuan dan fisik mereka. Karena itu, anak harus dikenalkan sedini mungkin mengenai pengetahuan kebencanaan, salah satunya melalui pendidikan di sekolah. Penyampaian materi kebencanaan dapat dilakukan melalui kegiatan pembelajaran sains. Artikel ini bertujuan untuk memaparkan berbagai metode dan bentuk aktivitas pembelajaran sains yang menyenangkan dan attraktif untuk menyampaikan pengetahuan kebencanaan agar dapat diterima oleh anak. Tulisan ini disusun melalui pendekatan metode kualitatif dengan penelitian studi dokumen. Pengenalan pengetahuan kebencanaan pada anak di sekolah merupakan bagian dari upaya mitigasi bencana non struktural melalui bidang edukasi.
\end{abstract}

Kata kunci: Mitigasi Bencana, Anak Usia Dini, Metode, Aktivitas, Sains

\begin{abstract}
.
Children are one of the most disaster-prone community members due to their limited experience, knowledge, and physical. Therefore, children must be introduced as early as possible about disaster knowledge through education at school. Teaching and learning of disaster material can be done through science learning activities. This article aims to describe various methods and science learning activities, which are fun and attractive to convey disaster knowledge comprehend by children. This paper using a qualitative method approach with document study research types. An introduction of disaster knowledge to children in schools is a part of nonstructural mitigation efforts through education.
\end{abstract}

Keyword: Disaster mitigation, Early Childhood, Method, Activity, Science

\section{PENDAHULUAN}

Indonesia yang terletak di jalur Pasific Ring of Fire (Cincin Api Pasifik) menyimpan potensi bencana yang sangat besar. Menurut data dari Badan Perserikatan Bangsa-Bangsa untuk Strategi Internasional Pengurangan Risiko Bencana (UNISDR), Indonesia menjadi Negara yang paling rawan terhadap bencana. Potensi bencana ini dilihat dari jumlah manusia yang memiliki risiko korban jiwa jika terjadi bencana. Risiko bencana yang dihadapi Indonesia tergolong tinggi. Menurut data Badan Nasional Penanggulangan Bencana tahun 2017, Indonesia menempati peringkat pertama untuk potensi bencana tsunami dari 265 negara yang disurvei UNISDR. Meskipun masyarakat Indonesia sudah akrab dengan adanya bencana yang datang silih berganti, namun tingkat kesadaran pemerintah maupun masyarakat masih rendah. Penyebab timbulnya banyak korban saat bencana adalah ketidaksiapan dan keidaksiagaan saat terjadi bencana, sehingga

Pembelajaran Sains Untuk Mengenalkan (Aldila Rahma) 250 
yang muncul justru kepanikan justru memicu jatuhnya banyak korban. Pemerintah menyadari bahwa mitigasi bencana adalah suatu hal yang sangat serius sejak terjadi bencana gempa bumi dan tsunami yang melanda Aceh pada tahun 2004. Walaupun dapat dikatakan terlambat, namun Indonesia sudah membangun sistem nasional penanggulangan bencana dari berbagai aspek misalnya dari sisi Legislasi, dimana pemerintah Indonesia mengesahkan Undang-Undang Nomor 24 Tahun 2007 Tentang Penanggulangan Bencana. Produk hukum turunannya antara lain Peraturan Pemerintah, Peraturan Presiden, Peraturan Kepala Kepala Badan, serta peraturan daerah. Secara kelembagaan, dibentuk BNPB merupakan lembaga pemerintah di tingkat pusat. Sementara itu, focal point penanggulangan bencana di tingkat provinsi dan kabupaten/kota adalah Badan Penanggulangan Bencana Daerah (BPBD). Serta dari sisi pendanaan terkait penanggulangan bencana yang bersumber dari dana APBN/APBD, kontijensi, on call, bantuan sosial (hibah), dari masyarakat dan dukungan internasional (Badan Nasional Penanggulangan Bencana, 2017)

Untuk membangun masyarakat sadar bencana, berbagai upaya telah dilakukan oleh pemerintah Indonesia. Pemerintah juga membangun sistem peringatan dini (sirine, detector, alat komunikasi dan sebagainya) di wilayah rawan bencana dan mensosialisasikan kepada masyarakat. Salah satu contohnya adalah TEWS (Tsunami Early Warning System). Selain itu dilakukan pula pelatihan atau simulasi penyelamatan diri (evakuasi), pelatihan medis dan teknik pertolongan pertama pada korban bencana (P3K), tanggap darurat dan rehabilitasi pasca bencana (Redaksi Butaru, 2011). Adapun melalui pendidikan formal, mitigasi bencana tidak masuk dalam mata pelajaran khusus namun terintegrasi kedalam beberapa materi pelajaran atau dijadikan muatan lokal.

Pendidikan mitigasi bencana sudah dicetuskan pada tahun 2012 melalui program sekolah aman yang berpedoman pada Peraturan Kepala BNPB Nomor 4 Tahun 2012 tentang Pedoman Penerapan Sekolah/Madrasah Aman dari Bencana. Hal ini bagian dari langkah nyata bahwa sekolah juga turut berupaya untuk mengurangi risiko akibat bencana. Dalam Undang-Undang Nomor 20 Tahun 2003 tentang Sistem Pendidikan Nasional pasal 32 ayat 2, juga telah mengakomodasi kebutuhan pendidikan bencana dalam terminologi pendidikan layanan khusus, yakni pendidikan bagi peserta didik di daerah terpencil atau terbelakang, masyarakat adat yang terpencil, dan/atau mengalami bencana alam, bencana sosial, dan tidak mampu dari segi ekonomi. Dalam proses pembelajarannya, materi kebencanaan dapat dipaparkan melaui teori atau disajikan dalam berbagai bentuk media agar anak paham mengenai bencana tersebut (Arbai, 2015).

Pendidikan menjadi salah satu media dalam upaya mitigasi bencana nonstruktural melalui pengenalan kebencanaan untuk anak usia dini terutama melalui pendidikan formal di sekolah. Namun tentunya materi disampaikan pada anak sesederhana mungkin dan menyenangkan agar dapat dipahami, menarik, dan tidak menimbulkan rasa takut pada anak. Mitigasi bencana sangat penting dilakukan sedini mungkin, sebab jika terjadi bencana, anak-anak termasuk pada golongan masyarakat rentan bencana. Kelompok ini adalah anggota masyarakat yang membutuhkan bantuan karena keadaan yang disandangnya. Termasuk juga lanjut usia, penyandang cacat, serta ibu hamil dan menyusui (Kurniawan, Yunus, Mohd., \& Narwawi, 2011). 
Memberikan pendidikan kebencanaan sejak dini pada anak bersifat fundamental. Pendidikan dan stimulasi yang tepat pada usia dini akan menjadi modal penting bagi perkembangan anak dikemudian hari. Pada usia inilah ditanamkan nilai-nilai dasar dan mengembangkan kemampuan dasar dalam kehidupan. Pengenalan kebencanaan untuk anak usia prasekolah yang masih duduk di Taman Kanak-Kanak dapat disampaikan melalui pembelajaran sains. Pada dasarnya, sains adalah pengetahuan yang diperoleh melalui belajar atau latihan. Sains mencakup kebenaran umum atau pengoperasian dari hukum umum yang diperoleh melalui metode saintifik dan fokus perhatiannya pada dunia fisik (Webster's New Collegiate Dictionary, 2018). Pengetahuan kebencanaan sangat tepat diajarkan melalui sains, sebab anak dapat belajar untuk memperoleh pengetahuan dari fenomena-fenomena alam yang terjadi di lingkungan sekitarnya. Kegiatan sains akan membantu anak mengembangkan rasa ingin tahu dan terus mencari dan menemukan berbagai konsep pengetahuan dan dapat mengembangkannya seiring dengan bertambahnya usia anak.

Adapun tujuan dari tulisan ini adalah mendeskripsikan berbagai metode dan bentuk kegiatan pengenalan kebencanaan pada anak, melalui aktivitas pembelajaran sains di sekolah. Diharapkan tulisan ini dapat memberi informasi dalam pengembangan pendidikan pengurangan risiko bencana (PRB) untuk anak usia dini.

\section{METODE PENELITIAN}

Tulisan ini disusun menggunakan pendekatan metode kualitatif berjenis studi dokumen (document study), dengan menitikberatkan analisis berdasarkan konteksnya (Rahardjo, 2010). Teknik ini merupakan cara pengumpulan data melalui studi penelaahan terhadap buku, literatur, catatan, laporan, video, film yang relevan dengan masalah yang akan dipecahkan. Tahapannya yaitu identifikasi teori, pencarian pustaka, dan analisis dokumen (Nazir, 2003). Adapun sumber artikel ini berasal dari buku teks, jurnal, artikel internet, laporan penelitian dan video pembelajaran. Analisis data menggunakan teknis dari miles \& Hubberman melalui tringualasi data. Hasil yang dilihat adalah dengan melihat proses pembelajaran kebencanaan.

\section{HASIL DAN PEMBAHASAN}

\section{Metode Pengenalan Sains untuk Anak}

Dalam muatan kurikulum Pendidikan Anak Usia Dini yang tercantum dalam Permendikbud Nomor 146 Tahun 2014, terdiri dari program pengembangan nilai agama dan moral, pengembangan fisik motorik, pengembangan kognitif, pengembangan bahasa, pengembangan social emosional dan seni, sains masuk dalam program pengembangan kognitif. Standar tingkat pencapaian perkembangan anak pada usia 6 tahun yang tercantum pada Kompetensi Inti-3 (KI-3) pengetahuan, yaitu mengenali diri, keluarga dan lingkungan sekitar dengan cara mengamati dengan indera (melihat, mendengar, menghidu, merasa dan meraba), menanya, mengumpulkan informasi, menalar dan mengkomunikasikan. Adapula komptensi dasarnya yaitu kemampuan mengenal benda disekitarnya dan mengenal lingkungan alam (3.8) (Republik Indonesia, 2014b). Anak usia 4-6 tahun sudah dapat mengenal dan mengelompokkan benda berdasarkan kategori 
tertentu, mampu menghubungkan benda satu dengan lainnya atau menghubungkan benda dengan tulisan, hubungan seriasi.

Dalam mengenal lingkungan alam, indikator capaian perkembangan anak 4-6 tahun yaitu menunjuk nama dan kegunaan benda-benda alam, mencerutakan peristiwa alam dengan melakukan eksperimen, mengungkapkan hasil karya yang berhubungan dengan benda di lingkungan alam, menceritakan proses perkembangbiakan makhluk hidup. Adapula Lingkup perkembangan Kesehatan dan perilaku keselamatan sebagaimana tercantum pada Permendikbud Nomor 137 Tahun 2014, anak usia 4-6 tahun sudah dapat memahami berbagai alarm bahaya (kebakaran, kebanjiran, gempa), serta mengetahui situasi yang membahayakan diri. Sementara dalam lingkup perkembangan kognitif (belajar pemecahan masalah), anak diharapkan dapat mengenal konsep sederhana dalam kehidupan sehari-hari terkait lingkungan mereka, menunjukkan aktivitas eksploratif dan menyelidik, memecahkan masalah sederhana keidupan sehari-hari, menerapkan pengetahuan dan pengalaman baru, serta menunjukkan sikap kreatif. Dalam lingkup "berpikir logis", anak dapat mengenal gejala sebab akibat, adapula dalam lingkup "berpikir simbolik", anak dapat mengenal berbagai lambang dan mempresentasikannya (Republik Indonesia, 2014a).

Berdasarkan The National Science Education Standard, sains diajarkan melalui metode inkuiri (discovery inquiry) dengan pembelajaran langsung, eksplorasi untuk menjawab pertanyaan anak yang pada akhirnya mengarah pada penemuan konsep sains. Pengenalan sains juga dapat dilakukan melalui metode demonstrasi, dimana guru memberikan penjelasan, memberikan contoh dan melakukan percobaan dihadapan siswanya. Metode demonstrasi dapat membrikan ilustrasi dan menjelaskan informasi pada anak, dan dapat meningkatkan daya piker anak dalam kemampuan mengenal, mengingat, berpikir konvergen dan evaluatif (Cahyani, Jampel, \& Ujianti, 2015). Berikut ini beberapa metode yang dapat digunakan untuk mengajarkan sains di sekolah:

Eksperimen. Eksperimen atau percobaan adalah suatu operasi atau prosedur yang dilakukan dibawah kondisi tertentu untuk menggambarkan atau membuktikan suatu hipotesis (Webster's New Collegiate Dictionary, 2018). Kegiatan eksperimen menyajikan pembelajaran dimana anak melakukan percobaan dengan mengalami dan membuktikan sendiri sesuatu yang dipelajari (Djamarah \& Zain, 2006). Eksperimen merupakan bagian dari keterampilan proses anak dari dimensi sains.

Demonstrasi. Metode demostrasi memungkinkan anak melihat secara langsung proses terjadinya sesuatu. Metode ini dilakukan dengan memperagakan, menunjukkan, memperlihatkan proses tentang cara kerja suatu benda atau situasi tertentu yang sedang dipelajari, disertai dengan penjelasan lisan (Djamarah \& Zain, 2006). Demonstrasi dapat memperlihatkan secara konkret tentang apa yang sedang diperagakan serta membantu mengemabangkan kemampuan peniruan dan pengenalan cepat pada anak.

Field Trip/ Kunjungan/ Karyawisata. Metode karyawisata dilakukan dengan membawa siswa mengunjungi objek tertentu dan memberikan pengalaman belajar yang tidak diperoleh anak di kelas. Melalui field trip, anak memperoleh kesempatan untuk mengobservasi, memperoleh 
informasi dan mengkaji masalah secara langsung. Anak dapat diajak untuk mengunjungi museum, instansi terkait seperti BMKG, BNPB, BASARNAS, UPTD pemadam kebakaran dan sebagainya.

Games (Permainan). Bermain peran adalah salah satu bentuk permainan yang dilakukan untuk memerankan tokoh-tokoh, benda-benda, dan peran-peran tertentu sekitar anak. bermain peran merupakan kegiatan menirukan perbuatan orang lain di sekitarnya. Dengan bermain peran, kebiasaan dan kesukaan anak untuk meniru akan tersalurkan serta dapat mengembangkan daya khayal (imajinasi) dan penghayatan terhadap bahan kegiatan yang dilaksanakan (Risaldy, 2015). Belajar sambil bermain dapat menyenangkan dan menghibur bagi anak-anak. Bermain bagi anak adalah kegiatan yang serius tetapi menyenangkan. Melalui permainan, anak-anak juga dapat mengembangkan semua potensinya secara optimal, baik potensi fisik maupun mental intelektual dan spiritual. Oleh karena itu, bermain bagi anak usia dini merupakan jembatan bagi berkembangnya semua aspek (Zaini, 2015).

Cerita (Story Telling). Metode bercerita adalah memberikan pengalaman belajar bagi anak dengan membawakan cerita pada anak secara lisan. Konten ceritanya harus menarik perhatian anak namun tidak terlepas dari tujuan pendidikan (Moeslichatoen, 2004). Bercerita adalah salah satu upaya menanamkan nilai-nilai atau karakter. Melalui bercerita, anak dapat belajar mengembangkan imajinasi, mengekspresikan diri dan memetik hikmah dari cerita (Rahman, 2013).

\section{Bentuk Kegiatan Pengenalan Bencana Alam Pada Anak Melalui Pembelajaran Sains}

Berikut ini adalah contoh kegiatan pengenalan kebencanaan pada anak usia taman kanakkanak melalui pembelajaran sains di sekolah. Kegiatan ini merupakan bagian dari upaya mitigasi bencana melalui bidang edukasi.

\section{Erupsi Gunung Berapi}

Erupsi gunung berapi adalah salah satu bencana alam besar yang ditandai dengan keluarnya magma dari dalam perut gunung. Letusan gunung api merupakan bagian dari aktivitas vulkanik yang dikenal dengan erupsi. Penyebab terjadinya gunung api adalah keluarnya magma dari dalam bumi yang berasosiasi dengan arus konveksi panas, proses tektonik dari pergerakan dan pembentukan lempeng (kulit bumi), akumulasi tekanan dan temperatur dari fluida magma menimbulkan pelepasan energi (Nurjanah, Sugiharto, Kuswanda, BP, \& Adikoesoemo, 2012).

Mengenalkan bencana gunung meletus pada anak usia taman kanak-kanak salah satunya dengan cara melakukan eksperimen untuk meniru kejadian meletusnya gunung yang ditandai dengan keluarnya lahar berupa aliran magma dari kawah gunung. Pembuatan miniatur gunung berapi dan "lahar" nya dapat menggunakan bahan-bahan sederhana yang mudah diperoleh dari lingkungan sekitar. Bentuk gunung api dapat dibuat menggunakan tanah liat, gipsum atau bubur kertas. Bagian tengahnya dilubangi menyerupai lubang kepundan tempat keluarnya magma. Bahan lahar dibuat dari air, pewarna, baking powder, sabun cuci piring dan untuk menciptakan efek erupsi, ditambahkanlah cuka. Gunung berapi "meletus" ketika cuka yang bersifat asam bertemu 
dengan baking soda yang bersifal alkali dan menetralkan sifat asamnya. Reaksi tersebut menghasilkan karbondioksida yang menciptakan gelembung serta muncul suara (efek erupsi) yang akan keluar dari dalam gunung berapi buatan tersebut (Harpp, Koleszar, \& Geist, 2005). Melalui eksperimen ini, anak akan memahami bagaimana erupsi gunung berapi dapat terjadi. Guru juga dapat bercerita mengenai tanda-tanda gunung akan meletus dan juga akibat yang ditimbulkannya, baik dari segi kerugian maupun manfaat setelahnya.

\section{Tanah Longsor}

Tanah longsor disebut juga gerakan tanah, merupakan perpindahan material pembentuk lereng berupa batuan, tanah, atau material campuran yang bergerak ke bawah atau keluar lereng. Proses sederhana terjadinya tanah longsor dimulai dari air meresap ke dalam tanah yang akan menambah bobot tanah. Jika air tersebut menembus sampai tanah kedap air yang berperan sebagai bidang gelincir, maka tanah menjadi licin dan tanah pelapukan di atasnya akan bergerak mengikuti lereng dan keluar lereng (Vulcanological Survey of Indonesia, 2006).

Untuk mengenalkan longsor pada anak, dapat dilakukan eksperimen untuk simulasi proses terjadinya longsoran tanah, menggunakan pasir dan air sebagai bahan utama. Pasir disusun menjadi gundukan yang dianalogikan sebagai lereng gunung. Gundukan pertama tanpa diberi apapun, sedangkan gundukan kedua diberi rerumputan. Anak bisa mencoba menyiram kedua gundukan tersebut dengan air dan mengamati perbedaannya (Khifria, 2011). Guru memberikan penjelaskan bahwa longsor dapat terjadi karena hilangnya vegetasi yang dapat menahan tanah sehingga mudah terjadi erosi dan mengaitkan dengan kerusakan lingkungan yang dapat menjadi penyebab terjadi bencana tanah longsor. Salah satu usaha mitigasi lainnya dengan memberikan informasi tanda umum tanah lonsor seperti waspada jika ada lereng atau tebing yang retak setelah turun hujan dalam intensitas tinggi, muncul mata air baru dan kondisi tebing rapuh dengan kerikil yang berjatuhan (Sadisun, 2014).

\section{Angin Puting Beliung}

Angin puting beliung adalah angin yang berputar-putar dengan kecepatan lebih dari $63 \mathrm{~km}$ per jam. Angin puting beliung sering terjadi ketika siang hari dan sore hari di musim pancaroba. Angin puting beliung dianggap sebagai salah satu jenis angin yang berbahaya karena dapat menghancurkan apa saja yang dilewatinya. Puting beliung tidak dapat diprediksi secara spesifik. Fase terjadinya angin ini berkaitan dengan fase awan Cumulonimbus (Cb). Kemunculan angin ini umumnya ditandai dengan udara yang terasa panas dan munculnya awan putih yang berlapis-lapis (Cumulus), namun diantara awan tersebut terdapat awan berwarna abu-abu yang menjulang tinggi (Cumulonimbus). Awan ini mampu menimbulkan angin yang cukup besar hingga puting beliung (Redaksi Ilmugeografi, 2020a). Dalam pembelajaran sains mengenai fenomena alam, anak dapat belajar di luar kelas dengan mengamati bentuk-bentuk awan, merasakan hembusan angin dan merasakan dan melihat temperatur udara. Guru juga dapat menjelaskan bagaimana hujan dapat terbentuk.

Untuk memvisualisasikan angin puting beliung pada anak, dilakukan eksperimen dengan membuat simulasi angin puting beliung dalam botol. Pembuatannya sangat sederhana yaitu mencampurkan air, cairan pencuci piring dan glitter warna kedalam botol bening. Kemudian hanya dengan mengocok campuran tersebut dengan arah memutar. Anak dapat ikut mengamati apa yang

Pembelajaran Sains Untuk Mengenalkan (Aldila Rahma) 255 
terjadi dalam botol tersebut. Memutar botol dalam gerakan melingkar akan menciptakan efek pusaran air yang terlihat seperti putaran angina puting beliung mini. Glitter akan membuat pusaran air terlihat lebih jelas. Air dengan cepat berputar di sekitar pusat pusaran karena adanya gaya sentripetal (gaya dalam yang mengarahkan benda atau cairan seperti air ke arah pusat jalur melingkar) (Scince Kids, 2020).

\section{Gempa Bumi}

Pada dasarnya gempa bumi tidak membahayakan, namun justru goncangan pada bangunan, kerusakan struktur, bahkan perabotan atau sesuatu yang dapat berpindah, putus atau jatuh yang justru dapat menyebabkan korban luka bahkan korban jiwa. Dalam mitigasi gempa bumi, anak dapat diajarkan beberapa prinsip keselamatan saat gempa bumi dengan metode demonstrasi atau bermain peran dalam suatu drama yang bertemakan gempa. Anak diberi contoh dan melakukan simulasi sederhana latihan menunduk dan melindungi kepala. Anak juga belajar mengenali tempat yang aman di luar bangunan. Tempat ini harus berada jauh dari gedung, pohon, alat permainan, pagar, kabel, atau hal lainnya yang mungkin akan jatuh menimpa anak. Jadikan tempat tersebut sebagai spot untuk berkumpul jika terjadi gempa bumi atau bencana lainnya. Anak harus tahu ke mana harus pergi harus meninggalkan gedung dalam keadaan darurat.

Jika berada di dalam ruangan, ajari anak untuk menunduk, menutupi kepala dan berpegangan pada sesuatu yang kokoh. Jika goncangan terasa, segera untuk menunduk, cari perlindungan ke bawah meja yang kuat atau perabot lain yang kokoh, berpegangan pada objek tersebut (kaki meja) sampai goncangan berhenti. Ceritakan pada anak bahwa selama gempa bumi, bumi akan bergoyang seolah-oleh sedang berada di atas perahu. Jelaskan juga bahwa gempa mungkin akan menimbulkan bunyi keras, suara berderak, gemuruh dan dapat memicu alarm. Identifikasi tempat yang aman di setiap ruangan, dengan menentukan bangku atau meja kosong untuk berlindung, jauhi tembok, kaca, cermin, figura, rak buku atau objek berat lain yang mungkin runtuh (Federal Emergency Management Agency, 2006).

\section{Banjir}

The Free Dictionary mendefinisikan banjir sebagai air yang meluap ke daratan yang biasanya kering. Banjir terjadi saat tanah tidak mampu lagi menyerap air, sehingga air akan mengalir. Jika limpahan air terlalu banyak dan bendungan tidak mampu lagi menampung air, terjadilah banjir (Scheidies, 2017). Guru sebelumnya menjelaskan siklus air menggunakan diagram bergambar, sehingga anak mengerti mengapa terjadi hujan. Eksperimen mengenai banjir dapat dilakukan dengan membuat miniatur lansekap. Gunakan beberapa nampan tahan air, masing-masing isi dengan jenis tanah yang berbeda (kerikil, pasir, tanah kebun, tanah liat, humus, kapur dan sebaginya). Anak dapat diminta untuk menyiramkan air yang dianalogikan sebagai hujan. Anak dapat mengamati tanah mana yang paling baik untuk menyerap air sehingga tidak terjadi banjir. Penyiraman dapat terus dilakukan sampai tanah-tanah tersebut tidak dapat menyerap air lebih banyak, dan terjadilah konsep "banjir".

Untuk anak yang tinggal di wilayah pesisir, dapat dikenalkan juga konsep Tsunami. Tsunami merupakan ancaman bencana alam yang kejadiannya seringkali tidak terduga. Tsunami merupakan perpindahan badan air yang disebabkan oleh perubahan permukaan laut secara vertikal yang berlangsung dengan tiba-tiba. Tsunami adalah jenis gelombang yang dapat bergerak ke segala arah 
hingga mencapai jarak ribuan kilometer. Anak dapat dikenalkan dengan tanda-tanda sebelum terjadi tsunami, seperti air laut tiba-tiba surut, tanda alam seperti gerakan angin atau perilaku hewan yang tidak biasa, terdengar suara gemuruh keras dari laut dan waspada jika baru saja terjadi gempa bumi (Redaksi Ilmugeografi, 2020b). Anak juga dikenalkan dengan simbol seperti simbol jalur evakuasi, juga sirine bahaya. Jika terjadi sirine early warning system berbunyi, mereka harus pergi ke tempat yang lebih tinggi dan paham akan arah jalur evakuasi.

\section{Pengintegrasian Kearifan Lokal Dalam Pembelajaran Sains}

Pengintegrasian kearifan lokal dalam mitigasi bencana melalui pembelajaran sains juga tidak kalah penting. Respon masyarakat dalam memahami bencana alam tidaklah instan, namun terbentuk dari strategi adaptasi yang berlangsung lama yang dilakukan akibat adanya ancaman lingkungan. Kejadian bencana yang sering terjadi, memberikan pengalaman empiris bagi masyarakat. Masyarakat lokal pada suatu daerah tertentu umunya memiliki kearifan lokal dalam memprediksi dan melakukan mitigasi bencana di daerahnya. Pengetahuan tersebut berasal dari interaksi dengan lingkungannya. Contohnya, masyarakat yang tinggal di lereng Gunung Merapi Jawa Tengah, mempunyai kemampuan untuk memprediksi kemungkinan terjadinya letusan. Masyarakat di sana biasanya membaca tanda-tanda alam melalui perilaku hewan, seperti turunnya hewan-hewan dari puncak atau keluar dari hutan, burung-burung atau hewan lainnya mengeluarkan bunyi suara yang tidak biasa, atau adanya pohon-pohon di sekeliling kawah yang kering dan layu. Adapula masyarakat Simeulue di Sumatera, memiliki pengetahuan terkait Tsunami (mereka menyebut tsunami dengan istilah lokal yaitu smong). Ketika terjadi peristiwa Tsumami Aceh tahun 2004, korban dari daerah tersebut relatif kecil walaupun lokasinya berdekatan dengan Aceh, sebab para orangtua di daerah tersebut telah "pertanda" yang ditunjukkan oleh alam. Jika laut surut secara mendadak, kemudian banyak ikan yang menggelepar di garis pantai, maka akan terjadi bencana. Para tetua di sana kemudian memerintahkan agar penduduk Simeulue untuk mengungsi ke tempat yang lebih tinggi (Desfandi, 2014).

Anak-anak dapat diajari dan dibiasakan untuk mengobservasi fenomena-fenomena alam yang terjadi disekitarnya. Anak-anak dibiasakan untuk dapat mengamati tanda-tanda alam. Sehingga, jika menemukan fenomena yang tidak biasa, anak sudah memiliki sikap kesiapsiagaan terhadap bencana sedini mungkin dan pada akhirnya perilaku ini akan berlanjut sampai mereka dewasa. Dengan demikian, proses pembelajaran sains pada anak seperti yang telah dipaparkan, bertujuan agar pengetahuan dan gagasan mengenai alam sekitar dalam berkembang pada diri anak. Anak juga akan terbantu untuk dapat menjelaskan tentang gejala-gejala di alam. Selain itu rasa cinta terhadap alam sekitar dapat tumbuh, sehingga anak menyadari kebesaran Tuhan Yang Maha Esa.

\section{KESIMPULAN}

Anak-anak merrupakan bagian dari kelompok yang rentan terhadap bencana. Pengenalan bencana pada anak salah satunya adalah melalui kegiatan pembelajaran sains di sekolah. Metode dalam penyampaian materi bencana diantaranya melalui metode eksperimen, demosntrasi, kunjungan (field trip), permainan dan cerita. Adapun bentuk kegiatan yang dilakukan adalah pengenalan terhadap berbagai jenis bencana yang sering terjadi di Indonesia seperti erupsi gunung 
Jurnal Golden Age, Universitas Hamzanwadi

Vol. 04 No. 2, Desember 2020, Hal. 250-260

E-ISSN : 2549-7367

api, tanah longsor, angin puting beliung, gempa bumi dan banjir (termasuk tsunami). Selian itu, dapat pula melakukan integrasi kearifan local dalam menghadapu bencana, yang disesuaikan dengan karakteristik derah tempat tinggal anak..

\section{DAFTAR PUSTAKA}

Adi, N. P., \& Faisal, V. I. A. (2020). Analisis Kelayakan Materi Piaud Science Learning Media (PSLM) Berbasis Wonosobo Local Wisdom. Jurnal Golden Age, 4(01), 59-68.

Badan Nasional Penanggulangan Bencana. (2017). Sistem Penanggulangan Bencana. Retrieved from https://bnpb.go.id/sistem-penanggulangan-bencana

Cahya Nasrullah, A. Y. U., \& Reza, M. (2020). Pengembangan Buku Panduan Kegiatan Pembelajaran Mitigasi Bencana Kebakaran Pada Anak Usia 5-6 Tahun. PAUD Teratai, 9(1).

Cahyani, K. A., Jampel, I. N., \& Ujianti, P. R. (2015). Penerapan metode demonstrasi dalam pengenalan sains untuk meningkatkan perkembangan kognitif anak 1. E-Journal PG-PAUD Universitas Pendidikan Ganesha, 3(1), 1-11. https://doi.org/http://dx.doi.org/10.23887/paud.v3i1.5762

Desfandi, M. (2014). Urgensi Kurikulum Pendidikan Kebencanaan Berbasis Kearifan Lokal Di Indonesia. SOSIO DIDAKTIKA: Social Science Education Journal, 1(2), 191-198. https://doi.org/10.15408/sd.v1i2.1261

Dewi, R. S. (2019). Mitigasi Bencana Pada Anak Usia Dini. Early Childhood: Jurnal Pendidikan, $3(1), 68-77$.

Djamarah, S. B., \& Zain, A. (2006). Strategi Belajar Mengajar (Revisi). Jakarta: Rineka Cipta.

Federal Emergency Management Agency. (2006). Earthquake Preparedness. What Every Child Care Provider Needs to Know. Retrieved from https://www.fema.gov/media-librarydata/20130726-1452-20490-2572/fema-240.pdf

Harpp, K. S., Koleszar, A. M., \& Geist, D. J. (2005). Volcanoes in the classroom: A simulation of an eruption column. Journal of Geoscience Education, 53(2), 173-175. https://doi.org/10.5408/1089-9995-53.2.173

Khifria, M. (2011). Simulasi Tanah Longsor dengan Menggunakan Pasir dan Rumput. Retrieved March 3, 2018, from http://milatulkhifria.blogspot.com/2011/05/simulasi-tanah-longsordengan.html

Kurniawan, L., Yunus, R., Mohd., R. A., \& Narwawi, P. (2011). Indeks Rawan Bencana Indonesia (2nd ed.). Retrieved from https://bnpb.go.id/uploads/migration/pubs/441.pdf

Moeslichatoen. (2004). METODE PENGAJARAN DI TAMAN KANAK-KANAK (2nd ed.). Jakarta: Rineka Cipta.

Nazir, M. (2003). Metode Penelitian (5th ed.). Jakarta: Ghalia Indonesia.

Ningtyas, D. P., \& Risina, D. F. (2018). Pengembangan Permainan Sirkuit Mitigasi Bencana 
Jurnal Golden Age, Universitas Hamzanwadi

Vol. 04 No. 2, Desember 2020, Hal. 250-260

E-ISSN : 2549-7367

Gempa Bumi Untuk Meningkatkan Self Awareness Anak Usia Dini. Jurnal Caksana: Pendidikan Anak Usia Dini, 1(02).

Nuraeni, N., Mujiburrahman, M., \& Hariawan, R. (2020). Manajemen Mitigasi Bencana pada Satuan Pendidikan Anak Usia Dini untuk Pengurangan Risiko bencana Gempa Bumi dan Tsunami. Jurnal Penelitian dan Pengkajian Ilmu Pendidikan: e-Saintika, 4(1), 68-79.

Nurjanah, Sugiharto, R., Kuswanda, D., BP, S., \& Adikoesoemo. (2012). Manajemen Bencana. Yogyakarta: Alfabeta.

Rahardjo, M. (2010). Jenis dan Metode Penelitian Kualitatif. Retrieved from GEMA. Media Informasi \& Kebijakan Kampus website: https://www.uin-malang.ac.id/r/100601/jenis-danmetode-penelitian-kualitatif.html

Rahman, M. M. (2013). METODE BERCERITA MEMBENTUK KEPRIBADIAN MUSLIM PADA ANAK USIA DINI. ThufulA, $1(1), \quad 75-87$. https://doi.org/http://dx.doi.org/10.21043/thufula.v1i1.4242

Redaksi Butaru. (2011). Posisi Indonesia dan Kerentanan Terhadap Bencana. Retrieved from http://tataruang.atr-bpn.go.id/Bulletin/upload/data_artikel/posisi indonesia.pdf

Republik Indonesia. Peraturan Menteri Pendidikan dan Kebudayaan Nomor 137 Tahun 2014 Tentang Standar Nasional Pendidikan Anak Usia Dini. , (2014).

Republik Indonesia. Permendikbud No. 146 Tahun 2014 Tentang Kurikulum 2013 PAUD (Pendidikan Anak Usia Dini). , (2014).

Risaldy, S. (2015). Manajemen Pengelolaan Sekolah Usia Dini (II). Jakarta: Luxima.

Sadisun, I. A. (2014). Pemahaman Karakteristik Bencana: Aspek Fundamental dalam Upaya Mitigasi dan Penanganan Tanggap Darurat Bencana. 1-11. https://doi.org/10.13140/2.1.3005.2485

Scheidies, C. (2017). A Flood Experiment to Do for Children. Retrieved January 4, 2018, from Sciencing website: https://sciencing.com/flood-experiment-children-10025793.html

Vulcanological Survey of Indonesia. (2006). Pengenalan Gerakan Tanah. Retrieved from https://www.esdm.go.id/assets/media/content/Pengenalan_Gerakan_Tanah.pdf

Webster's New Collegiate Dictionary. (2018). Science. Retrieved February 20, 2018, from https://www.merriam-webster.com/dictionary/science

Zaini, A. (2015). Bermain sebagai Metode Pembelajaran bagi Anak Usia Dini. ThufulA, 3(1), 118134. https://doi.org/http://dx.doi.org/10.21043/thufula.v3i1.4656 